\title{
A Democratic China?
}

\author{
Peter Emerson \\ The de Borda Institute, Belfast, UK \\ Email: pemerson@deborda.org
}

Received 9 April 2014; revised 16 May 2014; accepted 7 June 2014

Copyright (C) 2014 by author and Scientific Research Publishing Inc.

This work is licensed under the Creative Commons Attribution International License (CC BY).

http://creativecommons.org/licenses/by/4.0/

c) (i) Open Access

\begin{abstract}
Many are the criticisms of those who feel that the one-party state in China is inadequate, and many are the calls, especially from abroad, for reform. But would a democratic China-as per a western interpretation-be an improvement? In tackling this question, this paper concentrates on voting procedures: those used in elections and those (which may or may not be the same) used in decision-making. This article first looks at the USSR, Eastern and Central Europe, and then briefly at Africa. Next, it considers what could go wrong if a standard, western, multi-party democracy was to be adopted in China. And finally, it offers a more inclusive polity.
\end{abstract}

\section{Keywords}

\section{Consensus, Consensus Voting, Modified Borda Count (MBC), Power-Sharing}

\begin{abstract}
"Never have [we] Westerners had to take other peoples' views of us really seriously. Nor, like the representatives of all other great cultures, have we been compelled to take fundamental stock of our own culture... [Hence] the ultimate paradox, namely that [we] who have done more than any other people to create the modern world, are in certain respects the least capable of comprehending it” Paul A. Cohen.
\end{abstract}

(Jacques, 2012: 117).

\section{Introduction}

Many countries are now termed as democratic. In the 1950s and '60s, in Africa and elsewhere, various colonies gained their independence and now enjoy reasonably free elections and fairly stable governments. There have been and still are, however, many ghastly exceptions, not least Rwanda in 1994, where the western, adversarial, democratic structure was actually a catalyst of violence and, therefore, part of the problem. Similarly, in the 1980s, when the former communist states of the Soviet Union and Central Europe initiated policies of democratisation, success was widespread; the pain in some of the newly independent states, however, most especially in the Balkans, has frequently been extreme.

And so to China, where the question often arises: will the Communist Party of China, CPC, allow not only for 
economic changes, the sort that have produced such amazing growth over recent years, but also for a more democratic system of governance? For much of the $20^{\text {th }}$ century, the Union of Soviet Socialist Republics, USSR, exercised a considerable influence over its Eastern neighbour. Then, when Soviet communism did collapse, China watched from the side-lines as the various successor states suffered, not only an economic downturn, but in Moldova and the Caucasus, and closer to its own borders, in Tajikistan, inter-ethnic wars! A certain amount of caution in Beijing, therefore, is perhaps understandable.

Accordingly, with an emphasis on different voting methodologies for both elections and decision-makingfor these, after all, are the fundamental building blocks of any democratic structure-this article looks at other relevant jurisdictions of which the author also has personal experience, namely: Russia, the Caucasus, the Balkans, and briefly at Africa. Only then does it turn to China, initially to speculate on what might happen if the adversarial structures of current western practice were to be adopted, and then to ask if maybe a more consensual polity could be the wiser course to follow.

\section{The USSR and the Russian Federation}

In 1985, with the advent of perestroika, many assumed that the USSR/Russia would adopt both economic and democratic reforms. Sure enough, democratisation was initiated in 1988, albeit within the parameters of a oneparty democracy — an oxymoron to many foreign observers. Mikhail Gorbachev, however, was equally bemused by those who argued for a Russian variation of the US-party system. "Today the Republicans stand at the helm... tomorrow it will be the Democrats or the Republicans once again. There is no particular difference” (Gorbachev, 1987: 216).

Most advisers from abroad advocated "majoritarianism"-the western democratic model, i.e., majority rule by majority vote. It varies of course, but basically consists of a multi-party (or perhaps only two-party), parliamentary or presidential democracy, with elections under one of numerous systems, but with decisions invariably subject to a (simple or occasionally weighted) majority vote. What some western "experts" did not realise, however, was the fact that, on translation into Russian, this word "majoritarianism" reads "bolshevism"! (It comes from the word for "majority", bolshinstvo, whose members were thus the Bolsheviks; while their opponents, the Mensheviks, were of the "minority", menshinstvo. A new word has now been introduced into the Russian language: “majoritarnost”).

It was nevertheless decided that elections would be held within the one-party structure under the two-round system, TRS, the French model, and that decisions in Congress and any other elected chamber would indeed be by the ubiquitous majority vote.

\subsection{Majoritarianism and Bolshevism}

The consequences of adopting an adversarial polity were two-fold: they relate to the election and subsequent conduct of the Soviet Congress; and secondly, to inter-ethnic tensions in Azerbaijan, Georgia and Moldova.

\section{Democratisation in Moscow}

The first post-perestroika elections were held in 1989. For the first round, many candidates competed together; all, in theory, were communists... but in practice, while some were indeed red, others were just pink, a few distinctly blue, a small number green, some alas brown, and one or two somewhat uncertain. Campaigning was often in joint public meetings under an impartial chair, and in those sessions which the author was privileged to witness, the atmosphere was both friendly and constructive. In constituencies where the elections went to a second round, however, a majority vote run-off, it was all either/or, win-or-lose; so tensions increased, and these contests often became bitter and antagonistic. A less adversarial electoral system might have been a more sensible choice.

Congress, it was decided-or perhaps just assumed—was to operate under the "normal" rules of majority voting, and so too were all elected chambers, city councils and so on. As a result of employing similar norms, many parliaments elsewhere have divided into two opposing "halves"-the British and French, for example, into "left" and "right", the Americans into Democrats and Republicans. In like manner, many a political party has also split into two: in 1903, the All-Russian Congress of Social Democrats splintered into the Bolsheviks and Mensheviks, by "the accidental arithmetic of a single ballot" (Deutscher, 1982: 71); while in China, during 
the Cultural Revolution, the CPC divided into the two sides of mainstream and the gang of four. It was only to be expected, therefore, that this new Soviet Congress would also divide into two. It did not take long. One "half" was led by the Nobel peace prize winner, Mikhail Gorbachev, and the other by a second laureate, Andrei Sakharov.

Since then, under Boris Yeltsin and now Vladimir Putin, Russia has suffered from, initially, an economic collapse, and secondly, a rise in authoritarianism. It may now be asked, therefore, albeit in retrospect, was it wise to deploy such a majoritarian system, such that one side had a vested interest in the failures of the other?

\subsection{Inter-Ethnic Conflicts Post-Perestroika}

In nearly every former Warsaw Pact country, opposition to the ruling Communist Party succeeded in over-turning that administration, but that opposition then split into various factions. In some plural societies, the consequences were horrific.

Now according to international law, a country may exist if a majority within that jurisdiction so wills. The right of self-determination, first mooted in 1918 by US President Woodrow Wilson, was designed to be the principle by which colonies could gain their independence from their colonial masters, i.e., to resolve the external problem of imperialism. It was never intended to be that which it has now become, a basis by which a country can resolve any internal questions of secession. Furthermore, while the principle has been re-stated in many declarations, the methodology by which such determinations were to be effected was never stipulated. Article 2 of Resolution 1514, for example, passed on 14/12/1960, states that, "All peoples have the right to self-determination; by virtue of that right they freely determine their political status and freely pursue their economic, social and cultural development". It does not, however, define the word "people", nor does it say how that people shall "freely determine" their status if, as is often the case, the choice is restricted to just two options. Again, it seems, in many states, it was just assumed, not least by those in power who were drafting the referendum question, that the vote would be a standard yes-or-no majority vote.

In some circumstances, then, if a minority wishes to secede, and if a majority of that minority so wills, then it may. Alas, like those famous Russian dolls, matrioshki, and the equally well-known Chinese boxes, nearly every majority has its own minority. In effect, therefore, the rules governing the self-determination of nations were and still are a slippery slope to mayhem. This was first demonstrated in the British Isles in the 1920s, when Ireland chose to opt out of the UK, whereupon Northern Ireland chose to opt out of Ireland and opt back in to the UK. The "logic" could have been extended to certain enclaves like West Belfast which, like West Berlin, could have become part of Southern Ireland. The formula has no end... and hence the violence of 'the troubles' as the Northern Ireland conflict was called, 1969-1994.

In recent days, the problem has re-emerged in Crimea. The question, to paraphrase, was this: do you want to be Russian? and a second asked, do you want to be just a little bit Russian? So the majority voted in favour, while the minorities, the Ukrainians and the Tatars, abstained. The result is chaos in other regions, in Donetsk, Karkhiv and so on. The formula, "matrioshka nationalism” as the Russians call it, does indeed have no end.

\subsubsection{The Caucasus}

In drawing up the borders between the various Republics in the Caucasus, Stalin's cartographer was instructed to put all the Armenians into Armenia, and all the Azeris (and others) into Azerbaijan. Any villages or larger monoethnic groupings which did not conform to the new demarcations were to be put into "enclaves". Thus a village full of Gregorian Christians in Azerbaijan might be circled off to be included into Armenia; similarly, any Moslem villages in Armenia could be drawn as part of Azerbaijan. (A similar phenomenon occurred in the demarcation of borders between Tajikistan, Uzbekistan and Kyrgyzstan, and again, the post-perestroika consequences have sometimes been violent). One large enclave of mainly Armenians which was not included into Armenia was Nagorno-Karabakh.

For as long as the world operates on the basis that a majority may determine the status of all, such maps were a recipe for post-Soviet disaster. The first inter-ethnic clashes erupted in 1988 in the above enclave, NagornoKarabakh, and other disputes followed shortly afterwards in Georgia, in Abhazia and South Ossetia, both of which also resulted in wars. In all three areas, referendums have not helped at all; indeed, they have only exacerbated the problems, which remain to this day. 


\subsubsection{The Balkans}

While Russia was part of the Caucasian problem, at least in Abhazia where Moscow later deployed its own peacekeepers, the West was more involved in Yugoslavia. In 1990, the various Republics started to hold their first multi-party elections, mainly under the TRS system. The outcome of such a single-preference electoral system was two-fold: success for any "mono-ethnic"-or rather, "mono-religious"-party, and relative failure for any cross-community candidate such as Ante Marković of the Reform League.

In November 1991, with Serbia and Croatia already at war over the latter's attempt to secede, the European Union, EU, set up a Commission under Robert Badinter to look at Yugoslavia as a whole, and this group of five constitutional lawyers suggested that any people aspiring to independence should hold a referendum. Slovenia and Croatia had already held theirs, but more were to follow: and yet again, majorities voted in favour and minorities abstained. Some of these plebiscites were recognised, as in Bosnia; the one in Montenegro produced the "wrong" answer so it was repeated; the 1991 plebiscite in Kosova was initially ignored, but eight years later it became a cause of the NATO bombardment of Serbia, (Emerson, 2000: 49-50); and other plebiscites were dismissed, as in various enclaves-the Serb held Krajina in Croatia, the mainly Catholic Herzeg-Bosna and mainly Orthodox Republika Srpska in Bosnia, and the Sandžak in Serbia/Montenegro.

The overall result was mayhem. "The EU's insistence on referendums provided the impetus-whatever the spontaneous reasons (envy, hatred, competition) - to expel people from their homes and jobs on the basis of their ethnicity and to create ethnically pure areas through population transfers and expulsions as a prelude to a vote" (Woodward, 1995: 271). Then, on the day of the ballot, in Bosnia for example, the "barricades were thrown up by Serb militants”, (Glenny, 1996: 166), and the country was soon at war. Thus, as Sarajevo's legendary newspaper, Oslobodjenje, was to conclude, "all the wars in the former Yugoslavia started with a referendum" (op. cit., 7.2. 1999).

In summary, in the countries just mentioned, adversarial democratic structures exacerbated the problem. In Yugoslavia, elections were invariably held under a single-preference system-TRS or closed-list proportional representation, PR—so the outcomes were little more than sectarian headcounts. Similarly, all the referendums were dichotomous-for-or-against, yes-or-no—so any compromise options that might have existed were just not on the ballot paper. As a consequence, any Yugoslavs, or any partners in or children of a mixed marriage, or any who might otherwise have wanted to vote for compromise-like their counterparts in Northern Ireland's referendum of 1972, or in Crimea's of 2014-were in effect disenfranchised.

In the years that have followed since these wars, tensions have remained, especially in the more plural Bosnia. At the same time, all seven of these now nation states have asked to join the EU, and some have already done so. So what, one might ask, was the purpose of all those horrible wars?

\subsubsection{Africa}

Adversarial democratic structures have also caused mayhem in some African countries. Suffice here to mention just two instances of inappropriate electoral systems, and one of a bad decision-making system.

Firstly, then, the war in Côte d'Ivoire (Ivory Coast) in 2010 was in part provoked by the fact that the electoral system which preceded it was TRS, allowing as it thus did the final run-off vote to be between two antagonists from the previous civil war. Secondly, the post-electoral violence in Kenya in 2008 was similarly exacerbated by the use of first-past-the-post, FPP, electoral system: so every vote was single preference, and all too many of them were tribal.

So now, decision-making. Of those post-colonial states which did not conform to western norms, many became one-party states; some like Tanzania under President Mwalimu Nyerere became one of sub-Saharan Africa's first successful post-tribal nations, while President Yoweri Museveni in Uganda, not least because of the civil war, followed a similar policy. Such deviations from the western norms, however, were seldom viewed with western approval and, in more recent years, many one-party states have become multi-party democracies... often as a result of external influences, "donor democracy" as it is called, (Matlosa, 2007: 332), financial aid attached to certain "democratic reforms". That said, there have also been examples of appalling one-party states, as in Uganda of the 1970s, under Idi Amin, or in the Central African Republic under Bokassa.

The worst instance of an African nation suffering as a result of western democracy, however, was Rwanda. Throughout sub-Saharan Africa, "Majority rule was a foreign notion” (Mandela, 1994: 25). This is exemplified by the very words "baraza" (in Swahiliphone Africa), "gacaca" (in Rwanda) and "palabre" (in French West Africa), all of which imply a verbal consensus. But just as Western influences managed to prompt Africans to en- 
gage in European-style wars in the colonial era-the 1892 Battle of Mengo, for example, in today's Uganda, was part of a Catholic versus Protestant war-so too the very notion of majority rule was (not the but) $a$ cause of the 1994 genocide in Rwanda; the slogan used by the Interahamwe when they launched their genocide was Rubanda Nyamwinshi, "we are the majority people" (Prunier, 1995: 183), or, in other words, the Bolsheviks.

Africa, today, is still far from peaceful. Some countries have managed to exercise democratic changeovers of power via the ballot box, but majoritarian tensions still exist in many states, not least as the result of the introduction into Africa of self-determination by majority rule, as in the 2011 referendum in and subsequent independence of South Sudan, which is now falling apart.

\section{China}

The story of how rulers in China have related to the ruled, and whether or not any voting was used, covers many centuries. Initially, majority voting was used in “... the Court Conference of the Former Han Dynasty (202 BCE - $23 \mathrm{CE}$ ), and decisions were based on the opinion of the majority regardless of the position or rank of the individuals on either side. As a rule, [these decisions] were accepted by the Emperor" (Wang, 1968: 176). (At the same time, of course, the city states of Greece were devising a "demos", a more inclusive though still all-male and non-slave democracy, and here too majority voting was used, but in a democratic structure where there was “nothing resembling a 'party system”” (Ste. Croix, 2005: 198).

The rule in those "times”, it was explained by one of the dynasty’s most successful generals, Mă Yuán, was as follows: "it is not only the sovereign who selects his subjects. The subjects also select their sovereign" (Keay, 2009: 169). Indeed, the "mandate of heaven", which underpinned every dynasty, "in recognising the right of the people to rebel if the emperor failed them, was certainly a more democratic idea than its European counterpart, the divine right of kings" (Jacques, 2012: 275). Maybe too Confucianism was more democratic than pre-reformation and even some post-reformation denominations of Christianity.

Nevertheless, imperial rule was dictatorial, so inevitably, over the years, changes were mooted. Unfortunately, however, attempts such as the Minor Reforms of the $11^{\text {th }}$ century were regarded as criticisms of the Emperor and did not get very far; instead, the emperor's grip on power became tighter and tighter. Even when outside influences might have helped to create a less autocratic system of governance, as when the Jin dynasty came to power in 1122, the opportunity was not taken and instead, "Consensual institutions like the Jurchen chiefs' periodic councils [were] abolished" (Keay, 2009: 335).

The situation became critical, however, in the $19^{\text {th }}$ century, when the more powerful Western imperial powers fought the Opium Wars and then imposed the unequal treaties. In 1868, in an indirect response to yet another act of western gunboat diplomacy, this time by the US, Japan underwent a period of modernisation and westernisation, the Meiji Restoration. The consequence for China was yet another humiliation-defeat in 1894 by Japan in a war over Korea-whereupon many Chinese people realised that they too should modernise. First came the Hundred Days Reform, which the Dowager Empress Cí Xĩ squashed. Next was the 1900 Boxer Rebellion, with which she emphasised. And finally, albeit after her death, there came the revolution of 1911 and the end of the Qing dynasty altogether.

That which might have been the advent of a democratic China, the first election, was held in 1913. It was a contest in which "over three hundred... small political groups or parties” participated (Spence, 1999: 275), and the Guómíndăng (Kuomintang) of Sūn Zhōngshān (Sun Yat-sen) came out on top: 269 of the 596 seats in the upper house, and 123 of 274 in the lower (Brown, 2011: 8). Alas, the President, Yuán Shìkăi, who wanted to make himself yet another emperor, then banned this party altogether. The resulting chaos soon led to the terrible period of warlordism. By the mid-1920s, there were two parties-both of which believed in the notion of the one-party state, the Kuomintang and now the Communists-and both were competing against each other, often violently, to unite the country under one central rule. Then the Japanese returned: first in Manchuria in 1933 and, four years later, in China proper, occupying very quickly almost the entire Eastern sector.

1945, the end of WWII, brought no respite to China; that only came in 1949, with the Communists winning the civil war and forcing Jiăng Jièshí (Chiang Kai-shek) to flee to Taiwan. Shortly afterwards came a tragedy: ignoring any lessons that there might have been from the Soviet experience, Máo Zédōng forced through his own experiment in collectivisation, and the resulting death toll was measured in millions. Rules were made in Beijing, on the basis of which policies were enacted in collective meetings in the villages, with decisions of life and death sometimes subject to the local village vote. 


\subsection{Political Reform}

On the death of Máo, reform, both economic and political, was essential. The former was necessary, if only to ensure that starvation came to an end. The latter, too, was important, for if the peasantry were to continue under the centralised rule from Beijing, there would always be the possibility of a peasants' rebellion. Indeed, it was the "combination of lawlessness and economic mismanagement from 1949 onwards [which] were the driving factors behind the introduction of [village] elections after 1978. This at least gave governance in villages some semblance of legitimacy and popular support” (Brown, 2011: 18-19).

“The term 'political reform' was formally introduced into the modern lexicon of the Peoples' Republic of China, PRC, in a speech given by Dèng Xiăopíng in 1980” (Joseph, 2010: 108). It was a combination of rural democracy-for nothing yet was in the towns and cities-along with some more inclusive structures within the ruling CPC. Thus the June 1979 "new election law... sought to demonstrate a new spirit of democracy by insisting that contests for local People's Congresses should not be unopposed, and providing that any member of the electorate could stand [for office]" (Gittings, 2005: 160). That said, Dèng certainly had his reservations: "we should neither copy western democracy”, he said in 1987, "nor introduce the system of a balance of three powers” (Gittings, 2005: 179). The PRC, of course, was still a one-party state but, as noted above, such was the scenario when political reform was initiated in the USSR.

The Kuomintang, now in Taiwan, adopted a multi-party democracy in the 1980s. When Britain left Hong Kong in 1997, the latter also adopted a plural polity. China itself, despite such events as the democracy wall of 1978 and the 1989 protests in Tiān'ānmén Square, remains a one-party state, a “consultative democracy”, to use their current term.

\subsubsection{Today's Elections}

For the moment, then, elections are confined to the villages. Now anecdotal evidence suggests village democracy in China is not without its blemishes; but similar instances of fraud and cronyism can be found in many other parts of the world as well, not least in the author's own of Northern Ireland. Nevertheless, "The village election process has in effect been a massive act of education that has taught over 800 million people... the principles of Party and non-Party members running for power, of secret ballots, and of one person, one vote. It has also taught the principles of universal suffrage and of a choice of candidates. Village elections were not meant to be the seeds of anything else. But perhaps one day their introduction may be seen as a hugely significant moment when ideas of government being accountable to people who had the power to vote them in or out of power started to take root” (Brown, 2011: 69).

This village democracy is, of course, within the parameters of the one-party state-so it could be termed nonpartisan. In like fashion, local democracy in the US often tries to operate on a non-partisan basis; indeed, some smaller jurisdictions try to promote such a polity at both local and regional levels: the Canadian Inuit's region of Nunavut, for example, and the British island of Guernsey, both have no-party structures.

\subsubsection{The One-Party State}

A second aspect of the current scenario relates to whether or not single-party rule can be democratic. In many jurisdictions, especially in post-conflict zones, governance has been and sometimes still is effected via one form or another of power-sharing: the list includes Belgium, Bosnia, Kenya, Lebanon, Northern Ireland and South Africa. (For reasons unclear, the West usually advises newly-emerging democracies to adopt a majoritarian polity, initially; then, if and when it all goes horribly wrong, it suggests the very opposite, all-party power-sharing. The latest example is Ukraine.) Other, so-called stable democracies have also resorted to governments of national unity, GNU, in times of emergency: the UK, for example, had a coalition government during WWII. And one country, Switzerland, adopted a form of all-party rule without a crisis; in 1959, a "magic formula" of 2:2:2:1 was devised, such that the four largest parties formed a collective presidency. The formula is now 2:2:1:1:1 and five parties are involved, but "the magic" remains.

If, then, all-party governance is still democratic, might a one-party state also aspire to such an ideal? The example of Tanzania comes to mind, (see above), as does the theoretical possibility of a parliament in which every MP is an independent member. In fact, many an idealist has aspired to a non-party democracy: George Washington, for example, in his farewell address to the American people, first published on 17.9.1796, said, "the alternate domination of one faction over another... has perpetrated the most horrid enormities [and] is itself a 
frightful despotism”.

So maybe it is possible to have a one-party democracy. Every party has its wings, of course, and with its rightists and deviationists, the CPC has been no exception. But every country has its wings too. In a majoritarian polity, parliaments tend to split into government versus opposition. In a more inclusive milieu, such as a GNU, everyone is expected to cooperate. So might it be possible to create a (no-party), one-party (or all-party) democratic structure such that no one faction has the sole right to rule, and no one leader the possibility of becoming "the elected dictator"— to use Lord Hailsham's description of Margaret Thatcher (Hailsham, 1978).

\subsubsection{A Western Democracy?}

The first question, however, is this: what would happen if elections were to be held in China under an open, multi-party, western system? Doubtless, in Xīzàng, (Tibet), there would be a Tibetan Party, with off-shoots in any neighbouring provinces which have a considerable Tibetan population, Sìchuān and Qīnghăi, for example. Doubtless, too, there would be a Wéiwú'ěr (Uighur) Party in Xīnjiāng, with again other Islamic parties in those provinces, mainly in the West or South, where there is a sizeable Moslem population. (For some reason, Moslems are regarded as an ethnic minority whereas Buddhists, Taoists and other religious groups are not.) There are, in all, 55 minorities, many of them in Yúnnán and Guăngxī, so here too there might be a proliferation of parties, with perhaps at least one more mono-ethnic party in Inner Mongolia.

If these parties were then to contest elections under a single-preference adversarial electoral system-the worst example of which is probably FPP but, as noted above, others such as TRS can also be very divisive-relationships between various parts of the population could well deteriorate, as seen in Kenya with FPP, and in Côte d'Ivoire and the Balkans with TRS, (see above). Single preference PR list systems are sometimes not much better. In these, the voter is allowed only one preference; in a closed list system, he/she may vote only for a party (and not for a particular candidate), so if the party is sectarian, then so too is the vote. An open system at least allows the voter to choose his/her favourite from the party's list of candidates. The more sophisticated open-list systems, meanwhile, such as that used in Switzerland, allow for multi-candidate voting, so the voter may cross the party and gender divides, not to mention any ethno-religious chasm.

Another multi-candidate electoral system is the alternative vote, $\mathrm{AV}$, so here too, the voters are able to cross any ethno-religious divides; indeed, in Papua New Guinea, PNG, an AV vote is only deemed to be valid if the voter has cast at least three preferences which, because almost every candidate has a tribal allegiance, means the voter must in effect cross the divide at least twice. The PR version of AV, PR-single transferable vote, PR-STV, also allows the voter to vote across-party, as does the quota Borda system, QBS, the latter rather more positively.

If such a win-win electoral system were to be deployed, tensions could perhaps be less bitter. That said, it must also be noted that PR often, in effect, tends to perpetuate sectarianism, allowing as it does the threshold for representation to be lower than would otherwise be the case under FPP, say. Even in Northern Ireland which enjoys PR-STV, many voters choose not to cross the party divide and to vote instead, as "instructed" by the party, only for that particular party's candidates; as often as not, the party asks voters to vote in a specified order of preference and, via such tactics of "vote management"—a democratic oxymoron—aims to gain maximum party advantage.

If, then, an adversarial electoral system were to be adopted in China, and if, subsequently, the various provincial assemblies and the national Congress were to take decisions on the basis of a (simple or weighted) majority vote, sectarianism would almost certainly become institutionalised. If, furthermore, the constitution were to allow any persons aspiring to self-determination to hold a majority vote referendum, then the very introduction of democracy, of western democracy, could herald the break up of China. Indeed, some have predicted that "a Chinese republic would quickly degenerate into mob rule with corrupt elections and incompetent politicians" (Nathan, 1986: 61). Or, to quote Xīnhuá, the Chinese news agency, "If China imitates the West's multi-party parliamentary democratic system, it could repeat the chaotic and turbulent history of the Cultural Revolution when factions sprung up everywhere” (Fenby, 2012: 163). Such a fate will not be tolerated by the current administration.

\subsubsection{Western Majoritarianism}

Sadly, "there is a surprisingly strong and persistent tendency in [Western] political science to equate democracy solely with majoritarian democracy and to fail to recognize [a consociational] democracy as an alternative and equally legitimate type” (Lijphart, 2012: 6). Not only that; not only is the adversarial model seen to be the one 
and only possibility but, ipso facto, other forms, including a more consensual polity, are often dismissed as undemocratic: "the Confucian ethos pervading many Asian societies stressed $\cdots$ the importance of consensus. [This attitude contrasts] with the primacy in American beliefs of... democracy" (Huntington, 1997: 225). So maybe, as was said by one Mr. Wú, “Westerners need to be a bit more modest. They don’t always have the right answers” (Brown, 2011: 101).

In fact, "the Western assumption of the majority's right to overrule a dissident minority after a period of debate does violence to conceptions basic to non-Western peoples. Although the Asian and African societies differ vastly among themselves in their patterns of customary action, their native inclination is generally towards extensive and unhurried deliberation aimed at an ultimate consensus” (Emerson R, 1966: 284). Though that quotation was referring to all of Asia, the same is true today in the Middle Kingdom: "the often stated desire in Chinese public life... before implementing a solution, [is] to aim for consensus (Brown, 2011: 77).

\section{A More Inclusive Polity}

A western and adversarial democratic structure, then, was not suitable for many post-colonial countries; was not suitable for many post-Soviet countries; and, this article suggests, would not be suitable for China. A more consensual polity, however, could be appropriate, and maybe the democratic structure should be such that, "out of any debate... there should be no winners or losers", to quote Nelson Mandela, speaking on his retirement at the final sitting of the first democratically elected South African parliament, 26/3/1999.

Consideration will now be given to decision-making, to the various ways by which, if but in theory, decisions could be made; and then to elections where again, there are a number of voting methodologies to choose from. What follows is, firstly, a critique of present decision-making structures; next, a brief overview of electoral systems; and then a description of an inclusive form of governance.

\subsection{Decision-Making}

Be it a meeting of the company board, a conference on climate change, a gathering of the local village council or a session of Congress, decisions on topics which are controversial and/or complex should rarely if ever be based on a dichotomy, a choice of only two options. The same could be said elsewhere, not least in parliaments and international forums such as the UN Security Council: in other words, in any society which aspires to the adjective "plural", decisions on contentious matters should not best be based on a for-or-against vote, or even a series of such binary ballots.

Majority voting is in fact the most inaccurate measure of collective opinion ever invented. Its disadvantages have long been known; in CE 105, Pliny the Younger was the first to realize that binary voting may not be able to cater for those occasions when there are more than two options on the table; and this deficiency was later confirmed by Le Marquis de Condorcet as the paradox of voting in the $19^{\text {th }}$ century, (McLean \& Urken, 1995: 4).

The main disadvantage of binary voting, be it in a simple or a weighted ballot, is obvious: the collective will of a given electorate cannot be identified by a majority vote, not least because that option has to be identified earlier if it is to be already on the ballot paper. A majority opinion may, perhaps, be ratified, if that is the authors of the question have either made a good estimation, that or engaged in extensive discussions with all concerned, to draft what they believe represents the consensus; this sort of procedure can be undertaken when there are relatively few participants, as in the UN Security Council. In a parliament of hundreds, a Congress of thousands, or a population of millions, however, it must be emphasised that a majority opinion cannot be identified by a majority vote. What a binary vote does do is this: it identifies, with certainty, not "the will of the people", not even the will of the majority, but rather, the will of those who wrote the question. Little wonder, then, that binary voting has been a chosen instrument of so many dictators: they draft the question and, on almost every occasion, the question is the answer. Thus majority voting has been used by the likes of Napoleon, Lenin, Mussolini, Hitler, Duvalier, Khomeini and Saddam Hussein; the list is long (Emerson, 2012: 143-150).

As mentioned above, a further disadvantage of the two-option majority vote is that it tends to divide those who are making the decision into two opposing camps and, in a multi-party democracy, these two then become entrenched opponents, opposing each other almost out of principle (unless, as sometimes happens in Germany, for example, the two parties concerned join together in a grand coalition).

What's more, as noted in the Balkans and the Caucasus, in any divided society, a two-option majority vote only serves to exacerbate those divisions, if not indeed to provoke war. There must be a more inclusive way. 


\subsubsection{The Modified Borda Count (MBC)}

In any plural society, on any topic which is either complex and/or contentious, there will invariably be more than two options "on the table"... or there should be. What follows, then, is a description of a set of procedures which could be followed.

One crucial step in decision-making, and certainly in any forum whose decisions affect the lives of millions, is to allow for any debate on controversial issues to be refereed. Accordingly, any newly elected assembly shall first elect a team of, say, three impartial and non-voting "consensors", as they are called. Their duties are outlined below.

When any subject comes up for debate, all members of the assembly shall be entitled to draft a policy option. Obviously, in a large meeting, not every member can sponsor a motion. Inevitably, however, those concerned will form into groups-by gender, interest, geographical region and/or whatever. Such groups-in any western parliament—would be called parties; but there is no reason why these groupings should be so institutionalized. Mr. X can work and vote with Ms. Y on one issue, but they may choose to have different priorities on another topic. Secondly, in any multi-option debate leading to a preference vote, such differences may be made manifest without any undue polarization. Thirdly, the protagonists of any one option will know that their chances of success will be that much higher, if indeed they manage to muster a number of supporters. The number of options on the table, therefore, will rarely be excessive but, if need be, the consensors will advise guidelines and/or edit the options. They will also draw up a list of all relevant options-as long as these comply with a given norm such as the UN Charter on Human Rights—and display this list, in full on a dedicated website, and in summary on a computer screen.

In the debate itself, participants shall be able to ask questions, seek clarifications, propose amendments, suggest composites, or even call for a new idea to be considered. As the debate proceeds, the number of options "on the table" may therefore vary. If at the end of the discussions, only one option remains, this may be taken as the collective will. If, as is more likely in most forums, there are a number of options still listed, then the chair may call for a vote. Each sponsor shall first be asked if they are content that their particular proposal is included in the final list, either verbatim or in composite. And when they are satisfied, all concerned shall proceed to the vote.

\subsubsection{The MBC Vote}

On any complicated topic, the consensors will aim to produce a final (short) list of about five options. The list must obviously be balanced, to reflect the full range of the debate, with options, as it were, evenly spaced.

Those involved shall then be asked to cast their preferences on the various options listed, and in a five-option ballot, it works as shown in Table 1.

The rule is as follows: in an MBC of $n$ options, the voter may cast $m$ options, where $n \geq m \geq 1$. Points are awarded to $\left(1^{\text {st }}, 2^{\text {nd }} \cdots m^{\text {th }}\right)$ preferences cast according to the rule $(m, m-1 \cdots 1)$. In effect, then, the voter is encouraged to cast a full ballot. If he casts just one preference, he gives his favourite a one-point advantage over the option he likes least. But she who casts all five preferences gives her favourite a four-point advantage over her least favoured option.

It must be pointed out, of course, that, if cast, a voter's $x^{\text {th }}$ preference always gets just 1 point more than his/her $(x+1)^{\text {th }}$ preference, regardless of whether or not he/she has cast that latter $(x+1)^{\text {th }}$ preference. In an $\mathrm{MBC}$, there is no especial weighting.

The rules may be slightly different in a prioritization: in a ballot of $n$ options where $n \leq 10$, the voters may be asked to list all $n$ options. If, however, the number of options, $N$, is such that $N>10$, then the voters may be asked to cast just their top $n$ preferences, in which case it is suggested $n=6$.

\section{Table 1. The MBC vote.}

If a voter casts only one preference, he gives his favourite just 1 point.

If another casts two preferences, she gives her favourite 2 points, and her $2^{\text {nd }}$ choice 1 point.

If yet another casts three preferences, he gives his favourite 3 points, his $2^{\text {nd }}$ choice 2 and his $3^{\text {rd }}$ choice 1 point.

So best of all.

She who casts all five preferences gives her favourite 5 points, her $2^{\text {nd }}$ choice 4 , and so on. 
Whether making a decision or a prioritization, nobody votes against any body or any thing. People vote only in favour of the options listed, albeit with varying degrees of enthusiasm. By voting in favour, the voter in effect acknowledges the validity of the option, i.e., the validity of his/her neighbour's aspiration. The MBC is an inclusive system.

The outcome is the option with the most points. In order to be successful, therefore, the protagonist will need lots of high preferences, a few middle ones perhaps, but very few low ones. It is therefore worth his while to talk to his erstwhile (majoritarian) opponents, so to persuade the latter to give not a $5^{\text {th }}$ but a $4^{\text {th }}$ or even a higher preference. Thus the MBC encourages dialogue; it is indeed an inclusive methodology, ideally suited to a no-party, one-party or all-party polity.

\subsubsection{The MBC Count}

When the points are totalled in any ballot, if all or most of the voters have cast full ballots, at least one option will be above the mean, and others below. There are a number of possible scenarios.

1) If the winning option has a very high score, then obviously, the other options will be close to or below the mean, and such a well-regarded option may be described as having near unanimous support. If the top score is rather less, then maybe consensus is a better term, or maybe just best possible compromise.

2) If two options are neck-and-neck, the consensors may choose to form a composite.

3) If the top score is only just above the mean, then other options must also be close to the mean, in which case there is no consensus and the debate should be resumed, with emphasis on the more popular options, especially if a cluster thereof is seen to have distinctly more support than the remainder.

4) If the purpose of the vote is a prioritisation of, say, six options, and if the results show a cluster of seven options to be more popular than the rest, then maybe the consensors will decide that the final short list should consist of seven options.

To facilitate the consensors in their work, every option is given a consensus coefficient; this is defined as the option's MBC score divided by the maximum possible score, and it ranges from 1.0 (which is unanimity) to 0.0 (total rejection). Prior to any debate, it must be decided at what level of consensus a policy option shall be enacted, and such a level shall be enshrined in standing orders. The latter may also specify the levels of support required for an option to be regarded as "a near unanimous opinion", "a consensus", or "a best possible compromise".

\subsection{Elections}

While decision-making systems around the world could, but do not, vary-nearly everyone uses the (simple, weighted, twin, qualified or consociational) majority vote-elections display a huge variety: some are proportional, a few are preferential, several work under thresholds and many with quotas; and they vary from good to bad to atrocious. The last category includes the single-preference forms such as FPP and that version of PRlist—-the conveyors of sectarian head counts listed earlier.

A good system, it could be argued, should work on the same basis as the MBC, i.e., it would enable the voter to show support for various candidates (but not to display disdain for any others); it would encourage the voter to cross any gender and ethno-religious divides; and if a quota is used, it would also ensure a proportional result. Above all, it would be accurate and fair. The appropriate methodology is called the Quota Borda System, QBS, (Emerson, 2007: 39-60).

\subsection{Good Governance}

In an MBC, if every voter has cast a full ballot, the outcome, the option with the most points, may also be described as that which gains the highest average preference. And an average, of course, involves every voter, not just a majority of them. Little wonder, then, that "the Borda count is significantly more consistent", i.e., more accurate, and therefore more democratic (Saari, 2008: 95), than other voting procedures.

If, on any topic deemed to be controversial and/or complex — that is, any topic which is multi-optional-majority voting were to be replaced by the MBC; if, in a nutshell, the MBC were to be adopted in any one forum, there would no longer be any justification for majority rule by majority vote in that forum. Instead, therefore, of the chamber dividing into two asymmetrical "halves", (see above), with the executive consisting of a single majority party or a coalition of two or more parties in a majority or grand coalition, the elected assembly would op- 
erate under a system of all-inclusive power-sharing, a GNU.

This could best be effected by means of a matrix vote, which is based on both a QBS and an MBC. Each member of the assembly would be able to vote, in order of preference, not only for those whom he/she wished to be in the executive, but also for the portfolio in which he/she wanted each of his/her nominees to serve. Because the matrix vote is PR, the outcome would inevitably be an all-inclusive executive in which, in the consensus of that assembly, each minister would be the one most suited for that particular ministry. The matrix vote, therefore, is also ideally suited to a no-party, one-party or all-party polity.

The democratic structure could then be as follows. The people elect the assembly by QBS; and assembly then elects an executive by a matrix vote, (Emerson, 2007: 60-85). The QBS electoral system would encourage the voters to vote across any societal divides, gender, ethno-religious or whatever. In like manner, the matrix vote would also encourage the elected members to vote in a similarly inclusive manner.

As has been demonstrated often enough in Belgium and Northern Ireland, an inclusive system of governance tends to falter if contentious questions are put to a dichotomous (simple, weighted, qualified or consociational) majority vote. If, however, China adopted a polity as described above; if all serious disputes in the elected chamber were to be resolved by MBC; and if all preferences cast by all members were always to be made public; then there would be a good chance that China could indeed become a fully "consultative democracy".

\section{Conclusion}

In its dealings with China, "the West frequently attaches political conditions concerning democracy" (i.e., as per a western interpretation of the term), (Jacques, 2012: 426). Furthermore, the "main plank of American soft power is the stress placed on democracy within nation-states: China, by way of contrast, emphasises democracy between nation-states-most notably in terms of respect for sovereignty” (Jacques, 2012: 470), and not least because some institutions, like the International Monetary Fund for example, use decision-making methodologies which are both majoritarian and loaded in favour of the US and other major economies.

A democratic China is of course possible. The introduction of a simple western democracy, however, an adversarial structure, would be far too dangerous. The wiser course would be to adopt an inclusive polity, based on preferential voting. Such a polity would only be peaceful, and therefore successful, if it were indeed inclusive and not based on an adversarial majoritarian model, the likes of which currently predominate in the West. Maybe the latter should also change.

\section{References}

Brown, K. (2011). Ballot Box China. London and New York: Zed Books.

Deutscher, I. (1982). Stalin. London: Penguin, 71.

Emerson, P. (2000). From Belfast to the Balkans. Belfast: The de Borda Institute, 49-50.

Emerson, P. (2007). Designing an All-Inclusive Democracy. Heidelberg: Springer.

http://dx.doi.org/10.1007/978-3-540-33164-3

Emerson, P. (2012). Defining Democracy. Heidelberg: Springer, 143-50. http://dx.doi.org/10.1007/978-3-642-20904-8_8

Emerson, R. (1966). From Empire to Nation. Boston: Beacon, 284.

Fenby, J. (2012). Tiger Head, Snake Tails. London, New York: Simon and Schuster, 163

Gittings, J. (2005). The Changing Face of China. Oxford: Oxford University Press, 160.

Glenny, M. (1996). The Fall of Yugoslavia. London: Penguin, 166.

Gorbachev, M. (1987). Perestroika. London: Collins, 216.

Hailsham, L. (1978). The Dilemma of Democracy. London: Collins.

Huntington, S. P. (1997). The Clash of Civilizations. London, New York: Touchstone Books, 225.

Jacques, M. (2012). When China Rules the World. London: Penguin.

Joseph, W. A. (2010). Politics in China. Oxford: Oxford University Press, 108.

Keay, J. (2009). China. London: Harper Press.

Lijphart, A. (2012). Patterns of Democracy (2nd ed.). New Haven and London: Yale University Press, 6.

Mandela, N. (1994). Long Walk to Freedom. London: Abacus, 25. 
Matlosa, K. (2007). Challenges of Conflict, Democracy and Development in Africa. Johannesburg: Electoral Institute for the Sustainability of Democracy in Africa, Eisa, 332.

McLean, I., \& Urken, A. (1995). Classics of Social Choice. Ann Arbor: University of Michigan, 4.

Nathan, A. J. (1986). Chinese Democracy. Berkeley, Los Angeles: University of California, 61.

Prunier, G. (1995). The Rwanda Crisis. London: C. Hurst and Co, 183.

Saari, D. (2008). Disposing Dictators, Demystifying Voting Paradoxes. Cambridge: CUP, 95.

Spence, J. D. (1999). The Search for Modern China. New York, London: W. W. Norton \& Co., 275.

Ste. Croix, G. E. M. (2005). Athenian Democratic Origins. Oxford: OUP, 198.

Wang, Y.-C. (1968). An Outline of the Central Government of the Former Han Dynasty. In J. L. Bishop (Ed.), Studies of Government Institutions in Chinese History (p. 176). Harvard-Yenching Institute Studies XXIII.

Woodward, S. L. (1995). Balkan Tragedy. Washington: Brookings Institute, 271.

\section{Abbreviations}

$\begin{array}{ll}\text { AV = IRV = PV = STV } & \text { Alternative Vote (in the UK) } \\ \text { BC } & \text { Borda count } \\ \text { CPC } & \text { Communist Party of China } \\ \text { EU } & \text { European Union } \\ \text { FPP } & \text { first past the post } \\ \text { GNU } & \text { government of national unity } \\ \text { IRV = AV = PV = STV } & \text { instant run-off voting (in America) } \\ \text { MBC } & \text { modified BC } \\ \text { PR } & \text { proportional representation } \\ \text { PNG } & \text { Papua New Guinea } \\ \text { PRC } & \text { Peoples' Republic of China } \\ \text { PV = AV = IRV = STV } & \text { preferential voting (in Australasia) } \\ \text { QBS } & \text { quota Borda system } \\ \text { STV = AV = IRV = PV } & \text { single transferable vote (in the UK) } \\ \text { TRS } & \text { two-round system } \\ \text { UK } & \text { United Kingdom } \\ \text { UN } & \text { United Nations } \\ \text { US } & \text { United States (of America) } \\ \text { USSR } & \text { Union of Soviet Socialist Republics } \\ \text { WWII } & \text { World War II }\end{array}$


Scientific Research Publishing (SCIRP) is one of the largest Open Access journal publishers. It is currently publishing more than 200 open access, online, peer-reviewed journals covering a wide range of academic disciplines. SCIRP serves the worldwide academic communities and contributes to the progress and application of science with its publication.

Other selected journals from SCIRP are listed as below. Submit your manuscript to us via either submit@scirp.org or Online Submission Portal.
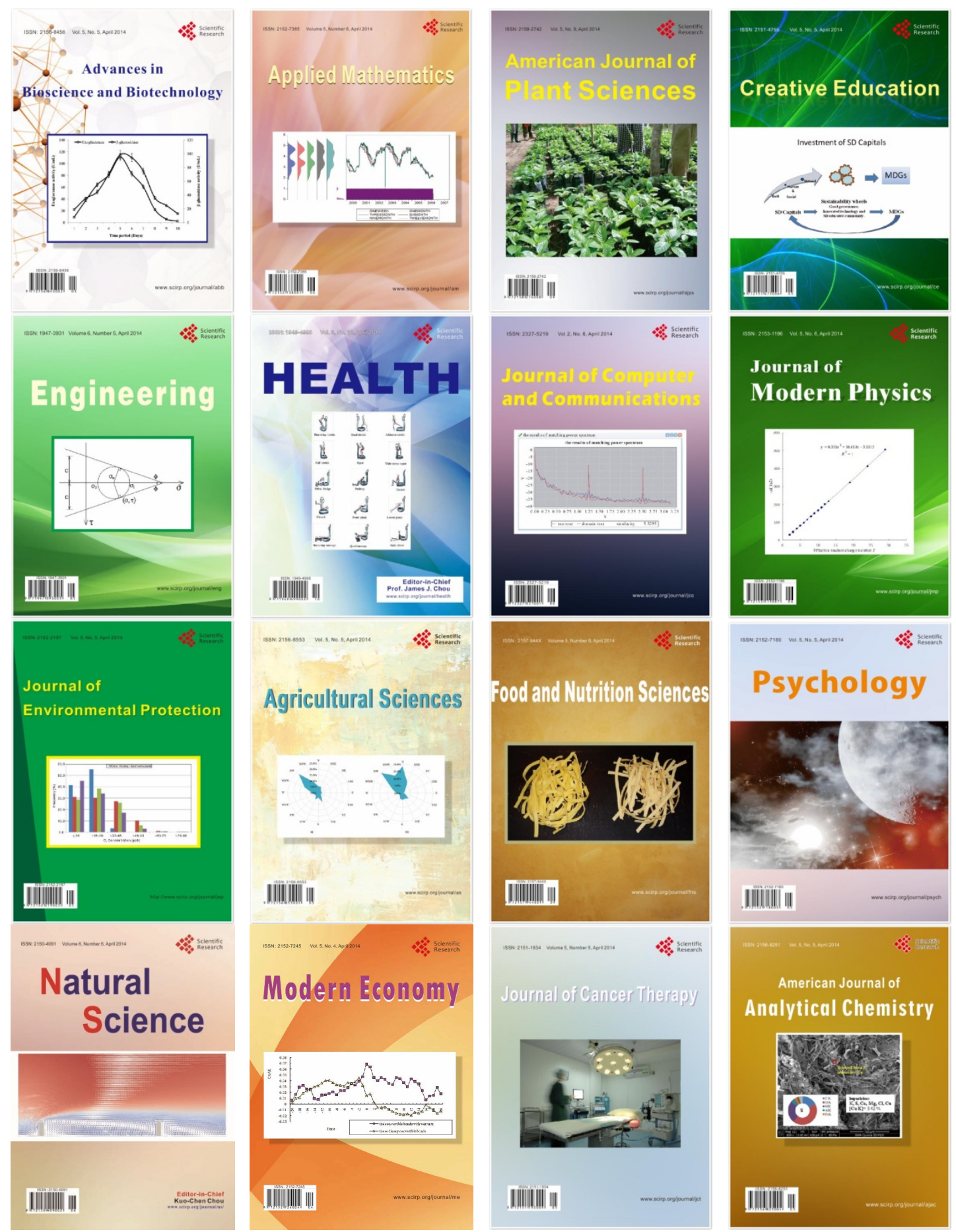